\title{
Moderna Lavoura Arcaica: \\ a ambivalência estrutural no cinema de arte
}

Renato Luiz PucciJfr

\section{Resumo}

O filme Lavoura Arcaica, dirigido por Luiz Fernando Carvalho (2001), é examinado segundo a perspectiva do "cinema de arte", uma das linhas do cinema moderno, segundo David Bordwell, de modo a se ressaltar sua dupla estrutura referencial, que combina elementos heterogêneos, por exemplo barrocos e românticos, numa forma ambigua que tem confundido a crítica especializada.

Palavras-chave: cinema de arte, ambigüidade, narrativa, romantismo, barroco.

\begin{abstract}
The film "Lavoura Arcaica", directed by Luiz Fernando Canalho (2001), is analyzed as belonging 10 "art cinema", one of the categories in modern cinematography, according to David Bordwell, in a way to emphasize its double referential structure, which combines heterogeneous elements, for instance, barroque and romantic ones, in an ambiguous way that has defealed specialized criticism.
\end{abstract}

Key words: art cinema, ambiguity, narrative, Romanticism, Baroque.

\footnotetext{
- Professor do Mestrado em Comunicação e Linguagens, na Universidade Tuiuti do Paraná, e autor de 0 Equilibrio das Estrelas - Filosofia e Imagens no Cinema de Walter Hugo Khouri (Annablume, 2001) e de artigos sobre cinema publicados na revista Significaçāo e nos livros da Socine.
} 


\section{Introdução'}

Há uma seqüência no filme Lavoura Arcaica (Luiz Fernando de Carvalho, 2001) que quase se repete. Quase. O trecho inicia-se com a imagem desfocada de pessoas num bosque. A voz de André, protagonista que também atua como narrador over (isto é, que narra a partir de um local e um tempo indefinidos), explica que é uma festa com parentes e amigos. $\mathrm{Na}$ agitação reinante, nada é visualmente bem definido, nem sequer as árvores em torno. A câmera faz um travelling para a direita, a exibir o recolhimento das toalhas que estavam no chão. No instante em que surge André, que caminha na direção contrária à do fluxo humano, o foco preenche toda a tela, tornando distinto o que até então era pouco mais do que manchas coloridas. Numa composição com ar de déjà $v u$, jovens sorridentes descem a encosta em passo apressado, enquanto o narrador comenta que entre eles estão suas irmãs, com "seu jeito de camponesas, nos seus vestidos claros e leves, cheias de promessas de amor suspensas na pureza de um amor maior". Vai ser formada a roda de dança. Um velho com turbante e flauta rústica, em que toca música árabe, introduz conotações étnicas e a idéia de que se trata de um ritual secular. Festejos, refeição e dança parecem provir de eras passadas, numa retomada cíclica que será confirmada no final de Lavoura Arcaica, quando haverá uma nova festa, com composição inicial idêntica à que está sendo comentada.

No livro homônimo de Raduan Nassar, o pai de André organiza a dança, com "mangas arregaçadas arrebanhando os mais jovens". No filme, o pai permanece à parte, o que lhe concede uma feição mais sóbria; apenas adiante será visto a dançar com a esposa no meio da roda. Em compensação, a imagem cinematográfica enquadra a multidão de corpos por trás, dos quadris às pernas, cada um tocando nos vizinhos de roda, nádegas femininas e masculinas a se movimentar numa efusão sensual perceptível apenas nas entrelinhas do livro (NASSAR, 2002: 29-30).

Ana, uma das irmãs de André, dança no meio de todos, agora sim num trecho repleto de sensualidade tanto em Raduan Nassar quanto no filme. Tal como descrito no livro, ela serpenteia os braços acima da cabeça, mãos graciosas girando, em selvagem elegância, dedos estalando como castanholas, ventre balançando (p. 30-32). Os presentes continuam a dançar, animados pela energia da moça. A tudo, de longe, assiste André, meio deitado, cabeça encostada numa árvore. A atmosfera é hipnótica, com a música ressoando e a imagem se alternando entre planos aproximados da irmã, a encher a tela com a volúpia de seus movimentos, e enquadramentos abertos, sempre a 
partir do ponto de vista de André. Os pés deste se afundam na camada de folhas sobre a terra, Leitmotiv que se repete a cada vez que reaparece o tema da sexualidade animal. Não é preciso mais do que esse derramamento de sensualidade para que se capte o desejo incestuoso de André. Ainda haverá uma cena com a mãe do rapaz. que chega por trás e lhe cobre os olhos (escurece a tela), para depois retirar as mãos e fazer com que a dança ressurja numa composição mais naturalista. à distância, som baixo, como se a tensão sexual amainasse um pouco. Ela acaricia o filho e convida-o a se juntar ao grupo, o que André recusa. O olhar langoroso confirma que está imerso em desejos pela dançarina à sua frente.

Um travelling lateral, sem cortes, parte de André deitado próximo à festa, para, numa elipse pouco comum no cinema atual, alcançar a imagem de seus pés no meio do mato, a fugir da fazenda, mochila às costas, até internarse num túnel ferroviário. Antes que se expliquem detalhes, está clara a ligação entre o desejo incestuoso, a fuga da casa familiar e a situação que abriu o filme e constitui seu presente narrativo: André num obscuro quarto de hotel, reencontrado por Pedro, o irmão mais velho. É a história de quem se desligou da família e que, de volta à casa paterna, deveria enchê-la de felicidade tal como na parábola bíblica do filho pródigo. Muito acontece entre a primeira e a segunda festa, que selaria o retorno de André. A narrativa se desvia de um caminho que deveria estar sancionado por uma sabedoria milenar. Irromperá uma fratura exposta na aparente solidez e felicidade que emana de trechos como o acima descrito, apesar de neste já existir o incômodo do desejo represado.

O elemento de ruptura será o incesto. Sabe-se disso desde cedo. pois Lavoura Arcaica não é um filme de mistério. O que merece maior atenção é a forma como são representadas a situação original e a explosão final. Durante o miolo da narração, tudo se articulará de maneira lenta mas implacável, a preparar o desenlace. Para se ter melhor idéia de Lavoura Arcaica, entendamse os caminhos por que o diretor optou na construção audiovisual da história. A polêmica levantada quando de seu lançamento talvez seja mais bem compreendida caso se percebam detalhes que possuem a peculiaridade de propiciar leituras heterogêneas. A aposta do presente trabalho é a de que se trata de um filme que merece exame cuidadoso a fim de que não se perca de vista sua relevância no panorama do cinema brasileiro, mas também para que deste se possa ter uma concepção mais sutil.

\section{A iconografia do paraiso}

Duas configurações distintas constituem a narrativa. De um lado. estão os flashbacks que apresentam a época anterior ao colapso resultante da transgressão do casal de irmãos e da fuga de André, nos quais o retrato da vida na fazenda possui caráter eminentemente romântico; de outro. há 
trechos sombrios, exaltados, sufocantes. Examine-se a primeira dessas configurações.

Não se trata apenas de amores apaixonados, ainda que existam nos flashbacks, mas, sim, da iconografia lírica própria de certa corrente do Romantismo. No cinema brasileiro, há reminiscências dela nos filmes pastoris de Humberto Mauro e, inclusive com um pai arcaico e guardião da moral, em Inocência (Walter Lima Jr., 1983), baseado romance de Visconde de Taunay. Mais usual em nossa cinematografia é a aridez do sertão nordestino, típica do Cinema Novo, ou sóbrias figurações do interior paulista, mesmo em filmes cômicos como A Marvada Carne (André Klotzel, 1985). Lavoura Arcaica retoma, em parte, uma linha menos comum e, com certeza, baseia-se em pinturas do século XIX, seja de origem nacional ou européia. ${ }^{2}$

Do primeiro flashback da infância de André, com o menino correndo pelo campo e se cobrindo com folhas ao deitar no solo, passando por inúmeras cenas do mundo rural, ressalta-se a natureza exuberante que, associada a imagens inocentes e à música suave, tende a produzir o flagrante clima campestre. Panorâmicas cobrem a fazenda, cujo terreno verdejante alcança o horizonte, exibindo os membros da família a trabalhar em harmonia. Janelas se abrem para a rica vegetação em volta da casa. Em escala mais reduzida, há o plano de detalhe do dente-de-leão que se desmancha ao vento, o garoto correndo por trás da cerca coberta de plantas, a luz do sol irradiando por entre as copas das árvores. Existem imagens compostas sem o menor pudor de radicalizar o caráter bucólico: duas vezes a menina Ana em meio às ovelhas, com um cordeiro nos braços, a encarnar a pastorinha do imaginário popular (de origem européia, mas que no Brasil se multiplicou em pinturas kitsch e folhinhas de calendário, representando a pureza infantil); o casal de irmãos, ainda criança, despeja leite numa vasilha, também em configuração estereotipada; o menino André pendura-se num galho, sob os olhos admirados do caçula, e pula feliz do alto do celeiro para um monte de feno. A chegada dos jovens ao local da dança na primeira festa, quando descem a encosta alegremente, é também uma composição inspirada na velha iconografia da vida rural.

O idílico combina-se com clichês rasgados da vida simples e honesta no lar. O soberbo trabalho de fotografia, de Walter Carvalho, enche os olhos com a beleza de partículas da farinha mais alva que flutuam pela cozinha enquanto o pão é feito pela mãe, ou da luz matinal que penetra pelas janelas da sala em que as mulheres recolhem louças e talheres. Não há dúvida que em trechos assim procura-se exibir um mundo esplendoroso e sem mácula. 
Sabe-se bem o quanto ruínas impressionaram a imaginação romântica, não como lugares de abjeção, mas de reminiscência de algo maior e mais belo. Na casa abandonada, coberta de pó, piso arrebentado e janelas caídas se concre izará o incesto, num primeiro momento cobrindo a paixão com o aval da fantasia exaltada dos grandes amores da ficção. Não é parcimoniosa a iluminação: pouco antes de se deitar com a irmã, André, eufórico, chuta a palha do chão, fazendo-a esvoaçar lindamente na luz do sol que entra pela janela.

Tudo compõe uma figuração idealizada da vida interiorana. Note-se que esse aspecto é menos realçado no livro, que, entre as rememorações. apresenta o episódio dos amores do menino André pela cabra Sudanesa. com penetração no animal (p. 19-21). Por mais delicada que seja a escrita de Raduan Nassar, o trecho não é compatível com a pureza imaculada da parcela agreste da adaptação cinematográfica. O diretor e roteirista Luiz Fernando Carvalho levou ao extremo o contraste entre a singeleza romântica, que chega a resvalar no Kitsch. e a segunda fonte visual que inspirou o filme.

\section{A matriz barroca}

Flashbacks e comentários do narrador-over se processam fora de ordem cronológica, por isso não é possível definir com precisão quando surgem os problemas de André. Ele relembra ao irmão Pedro a influência da luz solar: "Essa claridade que passou a me perturbar...".

Seu rosto se contrai ao dizer isso, como se recordasse algo ruim; irrompe novo flashback, com a luz do sol entre as copas das árvores num dia modorrento; o som das cigarras se eleva até tomar conta da trilha sonora e se tornar francamente desagradável. Parece ser esse o ponto em que se anuncia o transtorno da vida familiar: entre a luz irradiante da infância e juventude e as partes sombrias da história de André, há o momento em que até o sol torna-se perturbador. Não é muito arriscado afirmar que esse trecho ecoa o sol ardente de $O$ Estrangeiro, de Camus. que ajuda a levar o protagonista a assassinar o árabe na praia. A luz abrasadora atormenta a sensibilidade de certos personagens.

O presente já fora visto sem romantismo. A abertura de Lavoura Arcaica, por exemplo, poderia ser chamada de "barroca", com tudo o que a palavra carrega de significados relacionados à tensão, crise e superabundância de elementos expressivos e conflitos de luz e sombra (WÖLFFLIN, 1989). Dos lençóis desfocados. manchas indistintas a cobrir a tela. passa-se ao corpo escuro e frenético de André, que se masturba. Escuta-se a aproximação de um trem, cujo som cresce à medida que André mais se excita. até a explosão sonora que sincroniza com a ejaculação. A poderosa visualidade desse trecho é composta com mínima profundidade de campo, 
que às vezes permite distinguir os poros do corpo em convulsão, enquanto nariz e olhos permanecem indistintos a centímetros da zona focada. A penumbra do quarto de hotel, onde André se refugiou após a fuga, produz o efeito de indefinição pictórica formulado por Wölfflin nas suas análises da pintura barroca (1989: 21-32). Desse modo, não se enxergam contornos, ou seja, não se sabe onde terminam os corpos, humanos ou não, e onde começa o que está ao seu lado. Recordando outro par de conceitos de Wölfflin, no caso, clareza e obscuridade (idem: 217-229), observa-se que por vezes a câmera passa da escuridão completa para o reflexo da luz de vela nos olhos do personagem, fazendo-os cintilar em meio à escuridão da imagem. Nada poderia ser mais diferente da clareza meridiana das cenas calcadas em fontes românticas. ${ }^{3}$

A composição do corpo de André, na abertura, também não é familiar aos pintores românticos, ficando mais próxima do barroco de Caravaggio: costelas afloram sob a pele tensa, músculos se retesam e se contorcem, enquadramentos sem harmonia. ${ }^{4} \mathrm{O}$ ângulo se inverte no instante do orgasmo, com o topo da cabeça de André a ocupar o primeiro plano e ao fundo, desfocado, o restante do corpo. Pouco depois, a imagem de André surge ao espelho, suja e deformada por uma grande-angular, enquanto a de Pedro imerge em sombras. Ao ouvir o sermão que Pedro lhe inflige, André responde com fúria, corpos e expressões tensionados ao limite.

Não só em relação ao visual faz sentido pensar em barroquismo, pois entre os temas centrais de Lavoura Arcaica há elementos típicos da cultura barroca, como o estado de tensão entre indivíduo e sociedade, a produzir gestualidade e expressão dramática exacerbadas (MARAVALL, 1983: 91).

Além do mais, constata-se um traço associável àquela que, até prova em contrário, é a mais barroca criação do cinema brasileiro: Terra em Transe (Glauber Rocha, 1967). ${ }^{5}$ Como o verborrágico Paulo Martins, André se esvai num dilúvio de palavras, ora despejadas sobre Pedro, ora sobre o pai. Ambos são filmes muito verbais, isto é, de retórica explícita, embora com objetos divergentes: a política no filme dos anos sessenta, o desejo no mais recente. Em Lavoura Arcaica, todavia, personagens importantes não têm a palavra, ou quase não a têm, casos de Ana, Pedro, a mãe e as outras irmãs de André. Também nesse aspecto o filme é clivado em duas tendências heterogêneas.

Ainda quanto à esfera visual, pode-se dizer que Terra em Transe define-se por uma pletora de elementos em sobreposição, de acordo com o horror vacui de composições barrocas, sejam pinturas seiscentistas européias ou altares das igrejas baianas do século XVII e XVIII. Em Lavoura Arcaica, por sua vez, há dicotomia entre as estéticas barroca $\mathrm{e}$ romântica, cada qual animando partes diferentes da narração e concorrendo entre si. 


\section{Arcaico e moderno}

Mais do que na imagem e na palavra, a dualidade se evidencia em tudo o que envolve o tempo. Parte da história encerra um abundante desfiar de figuras ligadas a épocas remotas. O pai reina com barba grisalha, postura patriarcal e sermões cujo espírito é mais afeito ao Antigo do que ao Novo Testamento. A caracterização é tão veemente que não é plausível exigir do personagem qualquer traço de naturalidade, seja nos gestos ou na fala. Naquela família de origem árabe e cristã. ele é o herdeiro do poder e da sabedoria transmitidos de geração em geração. O avô, já falecido, é a fonte da autoridade, por isso nos flashbacks cobre-se com imagens arcaicas: relógio cebolão, terno sóbrio, andar lento, barbas longas, juízo fatalista ("Makhtub" — "Está escrito", em árabe). Ao dar continuidade ao que foi transmitido pelo avô, o pai incorpora uma poeira secular.

A herança mais arcaica é a proibição do incesto, base da civilização e elemento contra o qual se levantam os irmãos. É a Lei maior que, de tão pressuposta, não é mencionada nos discursos do pai, que não divisa a sua afronta no comportamento dos irmãos e tampouco nos interstícios da vida doméstica: nas mãos da mãe sob o lençol em que está o filho ou no cheirar a roupa de baixo que está no cesto de roupa suja. Sucedem-se representações do mundo arcaico: na parede, o relógio com algarismos romanos; lampião; arado; mãe amassando a farinha para fazer pão: a feitura artesanal do queijo, cujo líquido pinga através do tecido: a bacia em que André toma banho; a menina Ana a experimentar o vestido feito pela mãe; a parábola do Faminto, visualizada segundo uma iconografia orientalizante; a idéia milenar da Mãe-Terra, que perpassa toda a figuração do mundo agrário de Lavoura Arcaica e se associa à fertilidade da mãe de André; e, ao final, a foice, instrumento que através da história tem encarnado tanto a Morte como o Tempo destruidor. ${ }^{6}$

A introdução desses elementos na caracterização da família dáThe uma feição longínqua em comparação com a família rural do início do terceiro milênio, que recebe imagens de TV via satélite e compra fora o que precisa. O campo perdeu sua característica mais arcaica quando deixou de ser auto-suficiente. No filme, o narrador André enfatiza que o pão sempre foi preparado em casa e comido três vezes ao dia, realçando a ritualização do alimento. Há longos planos com a mãe a amassar a farinha, e o Faminto come pão verdadeiro quando o Grande Senhor desfaz a simulação de banquete. O pão é um sinal do delineamento arcaico da família.

Elemento transcultural cuja iconografia se perde na história. atravessando Hesíodo e versículos da Bíblia, ${ }^{7}$ o tempo é assunto para os sermões do pai, que discorre sobre a estupidez de contrariar o seu 
fluxo, materializado no relógio do avô. $O$ tique-taque ressoa pela casa a marcar o fluir moroso e inexorável. Note-se que a narração absorve esse aspecto do tempo verbalizado pelo pai. Por isso, parte de Lavoura Arcaica transcorre de maneira pausada, sem pressa, como se o narrador contemplasse o passar dos acontecimentos. É o que sucede na maioria dos flashbacks, que, se por um lado obedecem à matriz romântica, de outro são encaminhados pelo ritmo que parece provir das palavras do pai.

Não é essa a única configuração do tempo em Lavoura Arcaica. Na abertura, como dito acima, a masturbação de André é acompanhada pelo estrondear da locomotiva, num crescendo audiovisual que chega ao paroxismo no momento da ejaculação. $\mathrm{O}$ ritmo sonoro, em aceleração vertiginosa, não se coaduna com o ritmo temporal anunciado nos sermões. Proponho que este se associe ao tempo-fluxo, e aquele ao tempo-explosão, que caracteriza também outros trechos, como a irrupção do menino André a correr pelo campo. Aos críticos que acusaram o filme de ser longo demais, pode ser dito que a duplicidade estrutural de Lavoura Arcaica engloba tanto cenas que fluem como um rio tranqüilo quanto cenas de narração explosiva. Parece-me que seria perdido o confronto básico da história caso a montagem fosse mais homogênea.

Diga-se de passagem que a masturbação de André no hotel foi descrita de forma bem diversa por Raduan Nassar:

o quarto é individual, é um mundo, quarto catedral, onde, nos intervalos da angústia, se colhe de um áspero caule, na palma da mão, a rosa branca do desespero, pois entre os objetos que o quarto consagra estão primeiro os objetos do corpo; eu estava deitado no assoalho do meu quarto, numa velha pensão interiorana, quando meu irmão chegou pra me levar de volta; minha mão, pouco antes dinâmica e em dura disciplina, percorria vagarosa a pele molhada do meu corpo (p. 09-10).

Como se percebe, nenhuma referência diegética ou metafórica se faz à chegada de um trem, embora não cause espanto que tal imagem aflore no filme, visto que trens são associáveis ao cinema desde Lumière. Produto industrial da modernidade do século XIX, como o próprio cinema, o trem é uma imagem perfeita para representar o segundo vetor que orienta a narração e, assim, contrapor-se ao que se encarna nas figuras arcaicas. É pelo caminho do trem que André foge da fazenda, deixando o universo estagnado para penetrar no tempo progressivo, do qual outro índice pode ser visto na cena da chegada à cidade: André é enquadrado através do pára-brisa de um automóvel, símbolo por excelência da indústria do século $\mathrm{XX}$. 
Além do mais, a idéia do trem introduz o ritmo crescente e explosivo que sustenta a parcela exasperada da narração. Através da masturbação, associa-se esse ritmo ao fator que revolucionará a família: o sexo. Entre flashbacks do paraíso perdido e retornos ao presente convulsionado, estão os pólos inconciliáveis que entrarão em conflito surdo até que ocorra a ruptura final.

\section{Ilusionismo precário}

É preciso deixar claro que tanto nas composições derivadas da estética barroca como nas de origem romântica a opção do cineasta é basicamente antinaturalista. no sentido de ser contrária ao que o senso comum entende como real. Na cena em que o pequeno André acorda de manhã e prepara-se para ir à igreja, há um excepcional trabalho de iluminação e roteiro que, todavia, elimina a verossimilhança. Após o garoto pegar a medalha religiosa no criado-mudo, exibe-se a sombra dele numa das paredes do quarto. Devido ao foco reduzido. a imagem não é nítida, e a sombra ainda oscila sob o bruxulear da luz da manhã. $O$ efeito que se procura é o da expressão de um momento mágico da infância. Vê-se a sombra de André pôr a medalha acima da cabeça, de modo que a fita presa à medalha assemelhe-se a uma auréola. Em seguida, a sombra eleva-se pela parede, como se o garoto levitasse em ascensão aos céus, imagem bíblica que não é fora de propósito. A câmera permanece imóvel e a sombra desaparece no espaço off acima do enquadramento. A cena posterior é um sobrevôo no campo, em que se enxergam as plantações de uma altura de dezenas de metros, até alcançar a igreja. Novo corte, e em câmera baixa enquadram-se meninas chegando à igreja, até que as pernas de um garoto penetrem no espaço off a partir do alto, como se aterrizasse à frente das outras crianças. Observe-se que no trecho do livro lêem-se somente as palavras ditas pelo narrador over: "[...] e assim que eu me levantava Deus estava do meu lado em cima do criado-mudo, e era um deus que eu podia pegar com as mãos e que eu punha no pescoço e me enchia o peito e eu menino entrava na igreja feito um balão" (p. 27). Em outras palavras, toda a visualidade inverossímil é criação cinematográfica, solução para o que é metáfora no texto escrito.

A utilização da estética kitsch também se processa em sentido pouco naturalista. Sua presença é tão marcante que não há como não detectar que se proclama o clichê, ao qual, contudo, o filme não adere de forma absoluta, tendo em vista a existência de elementos antagônicos ao Kitsch.

Entre tantos aspectos antinaturalistas, impressiona a fidelidade literal das falas ao texto de Raduan Nassar. Caso houvesse dúvida 
quanto ao projeto antinaturalista do cineasta, para eliminá-1a deveriam bastar frases como a seguinte, enunciada por André ao pai: "Por ora não me interesso pela saúde de que o senhor fala, existe nela uma semente de enfermidade, assim como na minha doença existe uma poderosa semente de saúde" (p. 162). Não que seja uma proposta original, haja vista a quantidade de adaptações cinematográficas de Shakespeare que mantêm os diálogos originais; mas não é esse um procedimento comum no cinema nacional. Também nesse ponto, o filme oscila entre dois extremos: a inverossimilhança de camponeses a falar como nobres e, ao mesmo tempo, o relevo concedido a objetos e situações triviais: roça, lampião, mesa de madeira, sopa de feijão, roupas grosseiras, os mesmos elementos que compuseram histórias de Jeca Tatu e filmes de Mazzaropi, em que o linguajar dos matutos se distanciava infinitamente do que se escuta em Lavoura Arcaica. Trata-se, neste filme, de uma combinação que poderia ter resultado em paródia: estilo nobre e assunto vulgar (GENETTE, 1982: 29-30). Durante milênios, aos personagens humildes esteve vedado o estilo trágico, privilégio de reis, príncipes e demais personagens com título nobiliário; por isso, a cada vez que camponeses se punham a falar como Édipo ou Ulisses, surgia a paródia. Essa convenção teria começado a ser solapada com o cristianismo, que perante Deus igualava personagens de estratos heterogêneos; sofreu outro abalo considerável quando dramas burgueses mereceram tratamento sério na literatura e no teatro setecentistas (AUERBACH, 1998); no século XX já era 104 possível ouvir, sem risos, os camponeses de Garcia Lorca a se pronunciar em tom elevado. Lavoura Arcaica dá continuidade a essa linha, tanto que em nenhum momento o filme desliza para o paródico, nem ao menos involuntariamente. $^{8}$

A parábola do Faminto é o trecho mais antinaturalista. Enquanto o discurso paterno se sustenta na sabedoria do Antigo Testamento, portanto na cultura judaica, essa parábola é subsumida a uma composição de origem árabe (conforme o turbante do Grande Senhor e as palmas para que as mulheres sirvam as iguarias). A estranheza, que sugere um erro de registro iconográfico, é eliminável em vista da origem cristã-libanesa da família de André, que sorveu mitologia de duas tradições. O preto-e-branco impõe uma textura heterogênea, não sugerida pelo livro (p. 79-87), em que nenhuma drástica diferença estilística existe em relação ao restante da narrativa. Pertence também apenas ao filme a indicação explícita de que o Grande Senhor e o Faminto se identificam com o pai e André, de modo a se concretizar o que está nas entrelinhas do livro, ou seja, que a parábola se refere aos protagonistas da história principal.

A parábola poderia ser mera ilustração da sabedoria paterna, não fosse um elemento visual a realçar a duplicidade do que se conta. A seqüência é antecedida pela imagem do pai de André à mesa a iniciar mais um sermão: "Era uma vez um faminto...". Corta-se para imagens de um céu negro, com 
relâmpagos a iluminá-lo por instantes, o que deixa entrever um par de olhos humanos, sinistros na penumbra. Uma nota desarmônica já foi introduzida. Em seguida, o Faminto se submete ao Grande Senhor, que serve pratos imaginários em vez de lhe matar a fome. Como até o fim do banquete o Faminto de nada reclama, o Grande Senhor o elogia, diz que irá alimentá-lo por toda a vida em razão da paciência demonstrada e sela o veredicto entregando pão de verdade ao Faminto, que o devora. A narração do pai recebe um ponto final nesse momento. $\mathrm{O}$ trecho poderia ser assimilado a um certo naturalismo fake, mais próximo de versões hollywoodianas das Mil e uma Noites. No entanto, André transforma o ponto final em reticências, ou melhor, retrocede o curso da parábola e o desvia: o Faminto pára de fingir comer o nada que lhe é servido e dá um murro no Grande Senhor, que cai desacordado. As palavras finais do Faminto são as mesmas do livro: "Que queres, senhor, o espírito do vinho subiu-me à cabeça e não posso responder pelo que fiz quando ergui a mão contra meu benfeitor" (p. 87). A imagem é poderosa: em meio à iluminação recortada entre branco e negro, o olho desfocado e distorcido do Faminto contrasta com a visualização dos poros do nariz e da testa, o que concede figura maligna ao agressor. Assim, possui dupla conotação também a história dentro da história: o naturalismo falseado da versão oriental é substituído pelo expressionismo da versão de André, que assumiu a narração, subvertendo-a.

\section{A encarnação da hybris - e sua afirmação}

Existe algo de Crime e Castigo na trajetória de André: também ele, como Raskólhnikov, não paira acima da moral e da religião. O sofrimento moral é de tal maneira enfatizado que se pode julgar que o personagem mergulhará na culpa sem remissão. No nome "André", inclusive, ecoa o martírio do santo católico, o que parece plantar a história no terreno da religiosidade. Não prevalece, porém, essa tendência.

Atente-se um pouco mais para o protagonista. Em vista das promessas feitas a Ana após o incesto, deduz-se que até então André havia sido o filho indolente: "as coisas vão mudar daqui pra frente, vou madrugar com nossos irmãos, seguir o pai para o trabalho, arar a terra e semear". Opunha-se ele à laboriosidade de Pedro, que é visto na lavoura. André formula um voto semelhante ao final da discussão com o pai, quando afirma, cansado demais para persistir na resistência à moralização paterna: "Daqui para a frente, quero ser como meus irmãos, vou me entregar com disciplina às tarefas que me forem atribuídas...". Caso a percepção que o espectador tenha do personagem se limite a essa resignação, parecerá que o rebelde meio romântico se submeteu incondicionalmente às regras familiares. Mas, como em tudo nesse filme (e também no livro), sobrevém outro aspecto. Feitas as pazes com o pai. André vai de cabeça baixa ao quarto de Lula. o irmão mais moço. Ali, fica-se sabendo que o garoto também sonhava em fugir da fazenda e que odeia se 
submeter à disciplina e aos sermões do pai. Nesse momento, André parece uma sombra diante da energia juvenil de Lula, ainda mais que este $o$ acusa de haver fracassado ao retornar à família. É quando André se aproxima, faz uma carícia no peito do irmão e põe-lhe a mão na testa, como a estancar a reação espantada de Lula: "O que você está fazendo, André?". Corta-se para um plano de detalhe dos pés de André, que, dispostos na posição de quem está sentado na cama, sobem para o espaço off superior. Em suma, mal acabou de se render perante o pai, André tem relações sexuais com o próprio irmão caçula. ${ }^{1}$

André é o personagem do descontrole, mesmo que seu discurso seja enunciado em linguagem épica. Como o protagonista de Teorema (Pasolini, 1968), André tem relações com dois membros da família e não é necessário que a história continue mais um minuto para que se pressinta que outros parentes haveria em seu caminho. ${ }^{2}$ Note-se que, ao contrário de André, o anjo de Teorema não pertencia à família desestabilizada através do sexo, o que torna mais complexa a situação no filme brasileiro.

O lado possesso de André é visualmente carregado nos momentos de explosão emotiva. Quando vocifera contra Pedro no quarto de hotel, seu rosto se cobre com uma baba espessa que mais se assemelha a sêmen que a corrimento de nariz. Elementos como esse lhe dão um ar maléfico, em especial quando contrapostos à figuração tépida das cenas de caráter pastoral. É nesse conflito que se situa a ambigüidade: por mais que se fale de culpa e se 106 insinue um martírio, por mais que André pareça endemoninhado, o filme exalta a sua sensualidade. Teria sido banal representar o pai como um ser puramente repressivo, odioso e repelente, assim como não passaria de lugar-comum mostrar André sempre com ares simpáticos. Optou-se por mesclar as tonalidades, fundir os contornos, não separando tão nitidamente os personagens.

Há diversos elementos a indicar que a paixão de André tem o apoio não só da narração-over como também de instâncias narrativas que the são superiores, próprias do cinema. Mencionarei apenas um par desses indícios.

Em primeiro lugar, a forma enaltecedora com que o narrador over, o próprio André, comenta a dança de Ana na segunda festa. Como dito mais atrás, esta começa de maneira idêntica à primeira festa. No livro essa quase repetição é realçada pelo uso das mesmas palavras: "os movimentos irrequietos daquele bando de moços e moças, entre eles minhas irmãs com seu jeito de camponesas, nos seus vestidos claros e leves, cheios de promessas de amor suspensas na pureza de um amor maior" (p. 186). O caráter ritualístico é indicado nessa repetição, quase palavra por palavra, das duas descrições. Mas há divergências. A crítica já apontou que os tempos verbais passam do imperfeito (o iterativo, a repetição, o hábito) da descrição da primeira festa ("e era no bosque atrás da casa [...] era então que se recolhia a 
toalha (...]") para o perfeito da ação acabada ("e foi no bosque atrás da casa [...] foi então que se recolheu a tolha [...]"), o que dá a entender que o tempo cíclico deu lugar ao tempo linear e irrecuperável (PERRONE-MOISÉS, 1996: 65). No filme, a diferença se assinala também no campo visual. A segunda festa começa com um plano quase idêntico ao da anterior, isto é, a preparação do local para a dança, num longo travelling lateral que agora parte da direita para a esquerda e alcança não André, mas Pedro que, talvez próximo da demência, tem expressão atônita e parece alheio ao que the ocorre em volta. Além dos irmãos incestuosos, ele é o único a saber de tudo.

A pureza idílica da primeira festa está prejudicada, o que chega à tona pela dança de Ana, agora coberta com os adereços de prostituta que André colecionara em suas andanças por bordéis. Não é uma dança aceitável aos olhos da comunidade, que intervém através da mãe e das irmãs: Ana está como que enlouquecida, movendo-se sem parar, cobrindo-se de vinho, mostrando o corpo como não o fizera antes, como se executasse uma dança pagã. Ocorre que não poderia ser mais positiva a descrição feita pelo narrador over, com toda a força persuasiva de que é investido: "Ana [...] tomou de assalto a minha festa [...], assombrando os olhares de espanto, suspendendo em cada boca o grito, paralisando os gestos por um instante. mas dominando a todos com seu violento impeto de vida". A beleza estonteante das imagens, com Ana em câmera lenta a cometer sandices, leva a narração não pelo caminho enviesado da culpa ou da histeria patológica, mas para a afirmação da vitalidade da moça. Aqui se entende também a posição das instâncias narrativas superiores, pois é claro que não provêm do narrador-protagonista a câmera lenta e os enquadramentos que realçam a energia de Ana.

A reação do pai é o segundo ponto a sugerir que a narração se alinha à paixão dos irmãos. O desenlace trágico só acontece porque Pedro, o primogênito, que um dia iria substituir o pai, é o grande ingênuo da história. Ele acreditou piamente nos sermões que dizian que o irmão nunca deverá abandonar o irmão e que, mesmo nos piores momentos, a família acolheria a ovelha desgarrada; acreditou também que a verdade deve prevalecer sobre tudo. Por isso, Pedro vai ao pai e, com as melhores intenções, conta-lhe o que sabe, levando a tragédia ao clímax. A reação do pai não poderia ser menos benevolente: arranca Pedro do caminho e parte para cima de Ana com a foice em punho. Assim como a narração literária poupa o leitor da descrição da garola ferida ou morta, a cinematográfica omite a imagem de Ana após o ataque do pai, o que poderia levantar uma ponta de dúvida quanto às suas consequiências (embora as pétalas vermelhas da rosa que estava no cabelo de Ana, agora espalhadas pelo chão, não deixem margem razoável para supor que tenha sobrevivido). De qualquer modo, o conteúdo de sermões tonitruantes mostrou-se inoperante até em relação ao próprio pai: a sabedoria milenar cedeu à ira. 
Durante os créditos finais, já sem imagens, escuta-se um último sermão paterno: "O tempo é maior tesouro de que um homem pode dispor..." Há cortante ironia (não de André em sua função narrativa, mas da narração cinematográfica) em colocar como posfácio esse sermão que se encontra quase no início do livro (p. 53). Após o desfecho, nada poderia estar mais desacreditado do que o discurso sobre as virtudes da vida de acordo com o tempo-fluxo: o próprio pai se submeteu ao tempo-explosão, antes encarnado apenas por André e Ana.

\section{Conclusão}

Na classificação do cinema moderno formulada por David Bordwell (1985: 205-213), Lavoura Arcaica poderia ser entendido como um exemplar do cinema de arte, cuja principal característica é a ambigüidade controlada. ${ }^{3}$ Em outras palavras, o filme possui uma base no cinema clássico (contigüidade espaço-temporal, direcionamento narrativo para o personagem e demais características que produzem o ilusionismo) e, ao mesmo tempo, marca-se por intrusões da narração, o que tende a produzir lacunas de informação ou, ao contrário, possibilitar explicações contraditórias para os mesmos fatos: Ana foi conivente com o incesto ou teria sido seduzida (conforme sugere o metafórico flashback com o menino André e a pomba branca)? Por que chora a mãe na cadeira de balanço? Por

108 que mostrar o inseto no dedo de André quando ele está no quarto do caçula? Não há a proliferação de rupturas que caracteriza o cinema modernista mais radical, como em Terra em Transe ou em Bressane e Sganzerla, mas também não há como reduzir Lavoura Arcaica aos limites do cinema de matriz hollywoodiana.

O cinema de arte teve sua época de ouro entre os anos cinqüenta e setenta, quando surgiram cineastas como Bergman, Antonioni e, no Brasil, Walter Hugo Khouri, porém rareou nas décadas posteriores. Por isso, não é absurdo dizer que em termos de proposta artística Lavoura Arcaica mais se aproxima das realizações do cinema de décadas passadas que de produções atuais, que operam segundo paradigmas bem diferentes do aqui examinado.

A produção da ambigüidade é um dos fatores a propiciar leituras parciais, pois não é difícil que apenas o lado convencional seja percebido em filmes de arte, tal como nas figuras de gestalt, em que, ao se ver a figura, perde-se o fundo. Caso se enxergue apenas uma das faces da estrutura duplicada de Lavoura Arcaica, perderse-á o elemento fundamental da construção narrativa. O filme não é apenas lírico e pastoril, visto que tais aspectos se chocam com o barroquismo; não é apenas arcaico, pois anuncia o moderno; seus personagens não estão apenas imersos em culpa, pois a narração 
invalida o discurso moralizante e exalta os infratores; não é apenas lento, porque uma parcela da narração marca-se pelo tempo-explosão etc. É através da confrontação entre os componentes de cada par de características que a produção de sentidos surge em toda a extensão.

A ligação entre Lavoura Arcaica e o cinema de arte, aliada à desfaçatez com que o tema do incesto tem sido tratado no cinema, talvez deixe a impressão de que Lavoura Arcaica seja um filme extemporâneo.É possível que o seja, desde que se entenda esse "extemporâneo" não como anátema, mas como característica de obras realizadas segundo princípios pouco utilizados em sua própria época. Quando mais se fala que o cinema está contaminado pela TV (Baudrillard), que eliminaria o suposto privilégio cinematográfico do caráter imaginário, surge um filme que, realizado por alguém que fez seu nome na televisão, se apropria de estilos pictóricos, de forma altamente ligada ao imaginário, para abordar um tema vital: o conflito entre tradição e paixão.

\section{Notas}

1 Este artigo surgiu dos debates do grupo Kinusp, liderado pelo Prof. Eduardo Peñuela, a cujos membros agradeço as sugestões.

${ }^{2}$ Um exemplo de bucolismo novecentista que ecoa em Lavoura Arcaica: "O Campo de Trigo" (National Gallery, Londres), do pintor John Constable. Um caminho de terra por onde vão os carneirinhos, um cão vigiando, o pastor a beber água no córrego, animais e árvores à volta, céu azul com nuvens brancas, ao fundo um camponês e o campo de trigo. A pintura é de 1826, e seu autor foi um dos grandes nomes do romantismo europeu.

${ }^{3}$ Não é plausível que em Lavoura Arcaica confrontem-se as estéticas clássica e barroca. Aquela, no dizer de Wölfflin, envolve linearidade, composição planar, forma fechada, pluralidade e clareza. Não basta que as cenas sejam claras e equilibradas para ser "clássicas". A título de comparação, cito $A$ Barriga do Arquiteto (Peter Greenaway, 1985) como exemplo de filme construído, em boa parte, segundo a estética classicista. Assim, contrariando a perspectiva wölffliniana, sugiro que em Lavoura Arcaica se contraponham a estética barroca e a romântica.

"Compare-se com a "Deposição de Cristo", da Pinacoteca Vaticana, em Roma.

${ }^{5}$ Sobre o caráter barroco de Terra em Transe, v. MACHADO JR., 1997.

${ }^{6}$ Um clássico estudo dessa figura do Tempo, da arte antiga à barroca, com repercussões até na propaganda do século XX, está em PANOFSKY (1986: 69-89). 
7 V. PANOFSKY, 1986: 69-89, cuja análise do tempo não se limita à vertente destruidora.

8 Não são raras as paródias involuntárias no cinema brasileiro. Num exemplo retumbante, atores da Boca do Lixo tentavam falar português ao estilo de José de Alencar, em Luciola, o Anjo Pecador (Alfredo Sterheim, 1975).

${ }^{9}$ No livro, o homoerotismo é mais claro: “... a madrugada haveria também de derramar o orvalho frio sobre os belos cabelos de Lula, quando ele percorresse o caminho que levava da casa para a capela" ( $p$. 182): Em outras palavras, Lula faz o mesmo que Ana fizera após cometer o incesto com André.

10 Talvez não seja coincidência que surja no livro a palavra "teorema" (p. 185) três páginas após o trecho em que André tem relação sexual com Lula.

${ }^{11}$ Não se trata de dizer que não sejam artísticas outras formas de cinema, como as desenvolvidas por Eisenstein e Bresson ou, no âmbito nacional, por Glauber Rocha e Bressane. Cinema de arte é apenas o nome convencionado para uma específica forma cinematográfica, conforme exposto no texto.

12 Ver O Sopro no Coração (Louis Malle, 1971), Chinatown (Polanski, 1974), Eu e Forever (Khouri, 1987 e 1993). Nestes dois últimos, não há a 110 caso, pai e filha.

\section{Referências}

AUERBACH, Erich. (1998). Mimesis. São Paulo: Perspectiva.

BORDWELL, David. (1985). Narration in the Fiction Film. Madison: University of Wisconsin Press.

CARVALHO, Luiz Fernando. (2002). Luiz Fernando Carvalho sobre ofilme Lavoura Arcaica. Cotia: Ateliê Editorial. Entrevista.

GENETTE, Gérard. (1982). Palimpsestes - La littérature au second degré. Paris: Seuil.

GOMBRICH, E.H. (1986). Arte e Ilusão - Um Estudo da Psicologia da Representação Pictórica. São Paulo: Martins Fontes.

MACHADO JR., Rubens Ribeiro. (1997). Estudo da Organização do Espaço em Terra em Transe. Tese (doutorado). Universidade de São Paulo, Escola de Comunicações e Artes.

MARAVALL, J.A. La Cultura del Barroco. 3. ${ }^{\text {a }}$ ed., Editorial Ariel, 1983, Barcelona. 
NASSAR, Raduan. (2002). Lavoura Arcaica. 3. "ed. São Paulo: Companhia das Letras.

PANOFSKY, Erwin. Estudos de Iconologia. Lisboa. Editorial Estampa, 1986.

PERRONE-MOYSÉS, Leyla. (1996). "Da Cólera ao Silêncio". In Cadernos de Literatura Brasileira, n. ${ }^{\circ}$ 2, vol. "Raduan Nassar". São Paulo: Instituto Moreira Salles.

WÖLFFLIN, Heinrich. (1989). Conceitos Fundamentais da História da Arte. São Paulo: Martins Fontes. 
112

CONTRACAMPO 13 